\title{
Pengaruh Corporate Governance dan Profitabilitas terhadap Penghindaran Pajak dengan Ukuran Perusahaan Sebagai Variabel Pemoderasi
}

\author{
Ni Putu Ayu Indira Yuni ${ }^{1}$ \\ Fakultas Ekonomi dan Bisnis \\ Universitas Udayana, Indonesia. \\ Email: ayuindiray97@gmail.com
}

\author{
Putu Ery Setiawan ${ }^{2}$ \\ Fakultas Ekonomi dan Bisnis \\ Universitas Udayana, Indonesia.
}

\begin{abstract}
ABSTRAK
Penelitian ini bertujuan untuk mengetahui pengaruh corporate governance dan profitabilitas terhadap penghindaran pajak denganukuran perusahaan sebagai pemoderasi.Jumlah sampel yang dianalisis sebanyak 55 sampel perusahan makanan dan minuman yang terdaftar di Bursa Efek Indonesia (BEI) tahun 20132017. Penentuan sampel menggunakan teknik purposive sampling. Analisis data penelitian menggunakan regresi linear bergandan dan analisis regresi moderasi. Hasil analisis menunjukkan kepemilikan institusional dan komisaris independen berpengaruh negatif terhadap penghindaran pajak. Profitabilitas berpengaruh positif terhadap penghindaran pajak. Ukuran perusahaan memperkuat hubungan kepemilikan institusional dengan penghindaran pajak. Ukuran perusahaan tidak mampu memoderasi komisaris independen dengan penghindaran pajak. Ukuran perusahaan memperlemah hubungan profitabilitas dengan penghindaran pajak.
\end{abstract}

Kata Kunci: Penghindaran Pajak; Corporate Governance; Profitabilitas; dan Ukuran Perusahaan.

\section{The Effect of Corporate Governance and Profitability on Tax Avoidance with Company Size as a Moderating Variable}

\begin{abstract}
This study aims to determine the effect of corporate governance and profitability on tax avoidance with company size as a moderator. The number of samples analyzed were 55 samples of food and beverage companies listed on the Indonesia Stock Exchange (IDX) in 2013-2017. Determination of samples using purposive sampling technique. Analysis of research data using multiple linear regression and moderation regression analysis. The results of the analysis show that institutional ownership and independent commissioners have a negative influence on tax avoidance. Profitability has a positive effect on tax avoidance. The size of the company strengthens the relationship of institutional ownership with tax avoidance. Company size is not able to moderate independent commissioners with tax avoidance. Company size weakens profitability relations with tax avoidance.
\end{abstract}

Keywords: Tax Avoidance; Corporate Governance; Profitability; And Company Size.

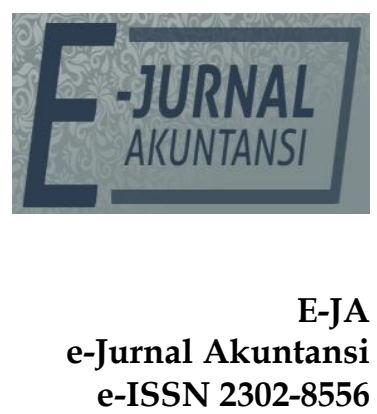

Vol. 29 No. 1 Denpasar, Oktober 2019

Hal. 128-144

Artikel masuk: 27 Juni 2019

Tanggal diterima: 30 Juli 2019 


\section{PENDAHULUAN}

Pajak merupakan salah satu sumber pendapatan negara yang digunakan untuk membiayai pembangunan nasional demi tercapainya kemakmuran dan kesejahteraan masyarakat. Pajak bersifat memaksa dan mengikat seluruh warga negara. Definisi pajak menurut Undang-Undang Republik Indonesia Nomor 16 Tahun 2009 Pasal 1 ayat (1) tentang Ketentuan Umum dan Tata Cara Perpajakan, menyebutkan bahwa "Pajak adalah kontribusi wajib kepada negara yang terutang oleh orang pribadi atau badan yang bersifat memaksa berdasarkan Undang-Undang, dengan tidak mendapatkan imbalan secara langsung dan digunakan untuk keperluan negara bagi sebesar-besarnya kemakmuran rakyat". Menurut postur Anggaran Pendapatan dan Belanja Negara tahun 2017 tercatat penerimaan pajak sebesar Rp1.498,9 Triliun atau sebesar 85,6 persen terhadap pendapatan negara yaitu sebesar Rp1.750,3 Triliun.

Sebagai sumber pendapatan negara terbesar, kepatuhan wajib pajak dalam membayar pajak dengan sukarela sesuai dengan peraturan perpajakan yang berlaku sangat diharapkan. Kepatuhan wajib pajak dalam membayar pajak akan membantu pemerintah dalam mengelola negara. Tingkat kesadaran masyarakat dalam membayar pajak dapat dilihat melalui tax ratio.

Alat ukur kinerja perpajakan Tax ratio merupakan pengukuran dengan membandingkan penerimaan perpajakan dan Produk Domestik Bruto (PDB) dalam kurun waktu tertentu.Rendahnya tax ratio menunjukkan masih rendahnya kesadaran masyarakat dalam membayar pajak, serta menunjukkan kemampuan pemerintah untuk menggali sumber penerimaan pajak dari berbagai sektor ekonomi juga belum optimal (Sindonews.com, 2016).

Tabel 1. Tax Ratio Indonesia Tahun 2013-2017

\begin{tabular}{ll}
\hline Tahun & $\begin{array}{l}\text { Tax Ratio } \\
(\%)\end{array}$ \\
\hline 2013 & 11,9 \\
2014 & 11,4 \\
2015 & 10,7 \\
2016 & 10,4 \\
2017 & 10,8 \\
\hline
\end{tabular}

Sumber: Informasi APBN 2018

Rendahnya kesadaran wajib pajakdalam membayar pajak berdampak pada berkurangnya penyetoran dana pajak kedalam kas negarasehingga akan mengganggu upaya pemerintah dalam meningkatkan kesejahteraan masyarakat. Rendahnya penerimaan pajak juga berdampak pada realisasi penerimaan pajak yang tidak sesuai harapan.Pemerintahmenetapkan target penerimaan pajak yang terus meningkat tiap tahunnya. Namun realisasi penerimaan pajak seringkali tidak mencapai target penerimaan pajak yang ditetapkan pemerintah. 
Tabel 2. Realisasi Penerimaan Pajak Tahun 2013-2017

\begin{tabular}{lcccc}
\hline Tahun & $\begin{array}{c}\text { Target } \\
\text { Penerimaan } \\
\text { (Dalam Triliun Rupiah) }\end{array}$ & $\begin{array}{c}\text { Realisasi } \\
\text { Penerimaan Pajak (Dalam } \\
\text { Triliun Rupiah) }\end{array}$ & $\begin{array}{c}\text { Persentase } \\
\text { Realisasi } \\
\text { Penerimaan Pajak } \\
(\%)\end{array}$ \\
\hline 3 & 201 & 995,21 & 921,27 & 92,57 \\
4 & 201 & $1.072,37$ & 981,83 & 91,56 \\
5 & 201 & $1.294,26$ & $1.060,84$ & 81,96 \\
6 & 201 & $1.355,20$ & $1.105,81$ & 81,59 \\
7 & 201 & $1.283,56$ & $1.151,13$ & 89,68 \\
\hline
\end{tabular}

Sumber: Data Penelitian, 2019

Faktor penyebab tidak tercapainya target penerimaan pajaksalah satunya adalah adanya upaya penghindaran pajak yang dilakukan oleh wajib pajak untuk mencapai efisiensi beban pajak. Penghindaran pajak dapat terjadi karena sistem pemungutan pajak di Indonesia yang menganut self assessment system, dimana wajib pajak orang pribadi maupun badan diberikan wewenang untuk menghitung, memperhitungkan, menyetorkan, dan melaporkan sendiri jumlah pajak yang terutang berdasarkan peraturan perundang-undangan perpajakan.Penghindaran pajak merupakan tindakan yang legal namun tidak disarankan oleh pemerintah.

Perusahaan sebagai wajib pajak dapat melakukan praktik penghindaran pajak.Penghindaran pajak perusahaan dapat terjadi akibat perbedaan kepentingan antara perusahaan sebagai wajib pajak dengan pemerintah sebagai fiskus. Perusahaan mengasumsikan bahwa pajak merupakan beban yangdapat mengurangi pendapatan, sehingga perusahaan sebagai wajib pajak ingin mengurangi jumlah pajak terutang dengan melakukan usaha atau strategi untuk meminimalkan jumlah pajak yang ditanggungnya, sehingga perusahaan cenderung memanfaatkan kelemahan peraturan (loopholes) perundang-undangan perpajakan.

Perusahaan go public diharapkan menerapkan corporate governance untuk mendorong terciptanya iklim usaha yang sehat bagi dunia bisnis sehingga dapat membantu perekonomian secara makro. Penerapan corporate governance dalam suatu perusahaan akan berpengaruh terhadap keputusan manajemen dalam pengambilan keputusan, salah satunya keputusan terkait kepatuhan pajak. Berdasarkan Pedoman Umum Corporate GovernanceIndonesia yang diterbitkan tahun 2006 oleh Komite Nasional Kebijakan Governance (KNKG), terdapat lima asas yang diperlukan untuk mencapai kesinambungan usaha, yakni transparansi, akuntabilitas, responsibilitas, independensi, serta kewajaran dan kesetaraan.

Kepemilikan institusional merupakan kepemilikan saham oleh pemerintah dan institusi lain diluar institusi pemegang saham publik (Ginting, 2016). Komisaris independen merupakan anggota dewan komisaris yang tidak terafiliasi dengan perusahaan tersebut. Komite audit merupakan komite yang 
bertugas mengawasi tata kelola perusahaan dan mengawasi audit eksternal atas laporan keuangan perusahaan (Damayanti \& Susanto, 2015). Kepemilikan institusional dipilih untuk memproksikan corporate governance. Kepemilikan saham oleh pemerintah, institusi keuangan, institusi berbadan hukum, institusi luar negeri, dan dana perwalian serta institusi lainnya disebut kepemilikan institusional (Ngadiman \& Puspitasari, 2014).

Karakteristik corporate governance lainnya yang digunakan dalam penelitian ini adalah komisaris independen. Pemilihan variabel kepemilikan institusional dan komisaris independen juga didasari karena masih ditemukan hasil yang kontradiktif pada penelitian terdahulu.

Selain corporate governance, salah satu faktor yang memengaruhi perusahaan untuk melakukan praktik penghindaran pajak adalah profitabilitas. (Anderson \& Reeb., 2003) menyatakan bahwa perusahaan yang memiliki profitabilitas yang lebih baik, terlihat memiliki nilai effective tax rates (ETR) yang lebih tinggi. Laba yang meningkat akan ikut meningkatkan jumlah pajak penghasilan perusahaan. Perusahaan yang memiliki profitabilitas tinggi memiliki kesempatan untuk memposisikan diri dalam tax planning yang dapat mengurangi jumlah beban kewajiban perpajakanLinet al.2013). Dalam penelitian ini, profitabilitas diproksikan oleh return on assets (ROA).

Berdasarkan penelitian terdahulu, ditemukan inkonsistensi hasil penelitian dari pengaruh kepemilikan institusional, komisaris independen, dan profitabilitas terhadap penghindaran pajak. Menurut Praditasari \& Setiawan (2017) kepemilikan institusional berpengaruh negatif terhadap penghindaran pajak. Penelitian tersebut sesuai dengan penelitian Rosalia (2017) dan Ginting (2016), yang menunjukkan bahwa semakin tinggi tingkat kepemilikan institusional maka pengawasan yang dilakukan kepada manajer akan semakin baik sehingga tindakan penghindaran pajak semakin rendah. Namun hal ini bertentangan dari hasil penelitian Arianandini \& Ramantha (2018) serta penelitian dari Wijayanti \& Merkusiwati (2017) yang menyatakan bahwa kepemilikan institusional tidak berpengaruh terhadap penghindaran pajak.

Menurut Wijayanti \& Merkusiwati (2017) komisaris independen berpengaruh negatif terhadap penghindaran pajak. Hal ini sesuai dengan hasil penelitian Utari \& Supadmi (2017) serta Diantari \& Ulupui (2016). Hasil berbeda diungkapkan Putra \& Merkusiwati (2016) dimana dalam penelitiannya didapatkan hasil komisaris independen berpengaruh positif dan signifikan terhadap penghindaran pajak. Namun hasil penelitian tersebut bertentangan dengan penelitian Asri \& Suardana (2016) dimana didapatkan hasil komisaris independen tidak berpengaruh terhadap penghindaran pajak.

Penelitian ini menggunakan perusahaan manufaktur sub sektor makanan dan minuman yang terdaftar di BEI periode 2013-2017. Perusahaan manufaktur yang tergolong dalam industri pengolahan memberikan kontribusi tertinggi sebagai penyetor pajak dilihat dari per sektor usahanya dibandingkan sektor lainnya seperti sektor perdagangan, keuangan, dan pertanian. Kontribusi sektor usaha terhadap penerimaan Pajak Penghasilan (PPh) nonmigas dapat dilihat pada Tabel 3 berikut. 
Tabel 3. Kontribusi Masing-Masing Sektor Usaha terhadap PPh Nonmigas 2017

\begin{tabular}{ll}
\hline \multicolumn{1}{c}{ Jenis Sektor } & Jumlah Kontribusi \\
\multicolumn{1}{c}{ Usaha } & $(\%)$ \\
\hline Manufaktur & 31,8 \\
Perdagangan & 19,3 \\
Jasa Keuangan & 14,0 \\
Pertanian & 1,70 \\
\hline
\end{tabular}

Sumber: Artikel Kementrian Perindustrian, 2017

Pada Tabel 3 terlihat kontribusi industri pengolahan terhadap penerimaan $\mathrm{PPh}$ nonmigas mencapai 31,8 persen, diikuti sektor perdagangan sebesar 19,3 persen, jasa keuangan sebesar 14,0 persen, serta pertanian sebesar 1,7 persen.

Pemilihan sektor makanan dan minuman dalam penelitian ini didasari atas kontribusi yang diberikan oleh sektor industri makanan dan minumanterhadap Produk Domestik Bruto (PDB) di Indonesia yangberperan sangat baik dibandingkan dengan cabang industri lain. Pemilihan sektor makanan dan minuman juga didasari atas ditemukannya fenomena penghindaran pajak oleh PT Coca-Cola Indonesia (CCI). PT CCI diduga mengakali pajak sehingga menimbulkan kekurangan pembayaran pajak senilai Rp49,24 Miliar (Artikel kompas.com).

Teori keagenan atau agency theory menjelaskan hubungan antara manajemen perusahaan (agent) dengan pemilik (principal). Menurut Jensen dan Meckling (1927) teori agensi adalah hubungan yang didasari atas kontrak antara principal sebagai pemberi wewenang dan agent yang merupakan pihak yang diberi wewenang. Perusahaan yang memiliki profitabilitas tinggi memiliki kesempatan untuk memposisikan diri dalam tax planning yang dapat mengurangi jumlah beban kewajiban perpajakan Chen et al. (2010).

Teori biaya politik menjelaskan mengenai bagaimana ukuran perusahaan dapat mempengaruhi tindakan penghindaran pajak yang mungkin dilakukan perusahaan.Perusahaan dengan ukuran yang besar akan lebih menjadi fokus pemerintah dalam kewajiban perusahaan tersebut memenuhi kewajiban pajaknya sehingga dengan adanya perhatian tersebut dapat meminimalisir perilaku penghindaran pajak. Ukuran perusahaan yang semakin besar atau bertambahnya nilai perusahaan akan menarik perhatian para stakeholder lainnya seperti pemerintah, debitur, kreditur dan lainnya (Wirawan \& Sukartha, 2018). Hal tersebut berpotensi menimbulkan biaya politik yang lebih tinggi. Penghindaran pajak atau tax avoidance merupakan usaha meminimalkan beban pajak dengan memanfaatkan celah perundang-undangan sehingga tidak melawan hukum dan bersifat legal.

Pengukuran yang dapat digunakan untuk mengukur tingkat penghindaran pajak beragam. Penelitian ini menggunakan Cash Effective Tax Rate (CETR) untuk mengukur penghindaran pajak perusahaan. The Organization for Economic Cooperation and Development (OECD) menyatakan bahwa corporate governance merupakan seperangkat tata hubungan di antara manajemen perseroan, direksi, komisaris, pemegang saham dan para pemangku kepentingan lainnya. 
Penelitian yang dilakukan oleh Khurana \& Mose (2009) menyatakan bahwa besar kecilnya konsentrasi kepemilikan institusional akan memengaruhi kebijakan pajak agresif dalam perusahaan. Investor institusi akan melakukan kontrol untuk mengawasi manajemen agar dapat mengoptimalkan kinerja perusahaan dimana mereka menginvestasikan dana.

Menurut Peraturan Otoritas Jasa Keuangan nomor 57 tahun 2017, komisaris independen adalah anggota dewan komisaris yang berasal dari luar perusahaan efek dan memenuhi persyaratan sebagai komisaris independen. Persentase jumlah komisaris independen wajib paling sedikit 30 persen dari jumlah anggota dewan komisaris. Komisaris independen dapat menjadi ketua komite audit.

Keberadaan komisaris independen dalam perusahaan dipandang perlu untuk memastikan dewan komisaris melakukan pengawasan terhadap kinerja manajemen sehingga tercipta tata kelola perusahaan yang baik. Keberadaan komisaris independen diharapkan mampu meminimalisir perilaku disfungsional dari manajemen seperti penghindaran pajak. Menurut Kotler (2012) Dewan komisaris yang belih canggih dalam finansial atau keuangan khususnya komisaris independen dapat mengurangi masalah keagenan terkait dengan penghindaran pajak yang ekstrim. Profitabilitas menunjukkan seberapa efektif suatu perusahaan dalam melaksanakan operasionalnya untuk mencapai tujuan perusahaan(Saputra \& Asyik, 2017). ROA dipilih sebagai prroksi untuk mengukur profitabilitas

Tabel 4. Kriteria Ukuran Perusahaan menurut UU No. 20 Tahun 2008

\begin{tabular}{cll}
\hline Ukuran Perusahaan & $\begin{array}{l}\text { Kriteria } \\
\text { Aset Bersih } \\
\text { (dalam Rupiah) }\end{array}$ & $\begin{array}{l}\text { Hasil Penjualan } \\
\text { (dalam Rupiah) }\end{array}$ \\
\hline Usaha Mikro & Maksimal 50 juta & Maksimal 300 juta \\
Usaha Kecil & $>50$ juta-500 juta & $>300$ juta-2,5 milyar \\
Usaha Menengah & $>500 \quad$ juta-10 & $>2,5$ milyar-50 milyar \\
Usaha Besar & $>10$ milyar & $>50$ milyar
\end{tabular}

Sumber: Undang-Undang Republik Indonesia No. 20 Tahun 2008

Menurut Rinaldi \& Cheisviyanny (2015) ukuran perusahaan menunjukkan kestabilan dan kemampuan perusahaan untuk melakukan aktivitas ekonominya. Namun, perusahaan besar cenderung menarik perhatian pemerintah terkait laba yang diperoleh dan fiskus dalam hal pembayaran pajak, sehingga manajer perusahaan dinilai akan bersikap patuh dan lebih transparan dalam menyajikan laporan keuangan.

Kepemilikan institusional memiliki peran penting dalam pengawasan terhadap manajemen perusahaan (Diantari \& Ulupui, 2016). Hubungan kepemilikan institusional dengan penghindaran pajak mengacu pada penelitian yang dilakukan oleh Ginting (2016) dimana hasil penelitian menunjukkan bahwakepemilikan institusional berpengaruh signifikan terhadap penghindaran pajak. Pada penelitian Praditasari \& Setiawan (2017) menyatakan bahwa kepemilikan institusional berpengaruh negatif pada tax avoidance.

$\mathrm{H}_{1}$ :Kepemilikan institusional berpengaruh negatif terhadap penghindaran pajak. 
Hubungan komisaris independen dengan penghindaran pajak mengacu pada penelitian yang dilakukan oleh Diantari \& Ulupui (2016) yang menyatakan bahwa komisaris independen berpengaruh negatif terhadap tax avoidance.Hal ini senada dengan hasil penelitian Wijayanti \& Merkusiwati (2017) yang menyatakan bahwa proporsi komisaris independen juga berpengaruh negatif pada penghindaran pajak.

$\mathrm{H}_{2}$ : Komisaris independen berpengaruh negatif terhadap penghindaran pajak.

Hubungan profitabilitas dengan penghindaran pajak dijelaskan dalam penelitian Praditasari \& Setiawan (2017) yang menemukan adanya hubungan positif antara profitabilitas terhadap penghindaran pajak. Hasil penelitian tersebut menunjukkan bahwa tingkat laba yang semakin tinggi akan beban pajak ikut meningkat seiring dengan meningkatnya laba yang didapat perusahaan. Hal ini dapat mendorong perusahaan untuk berupaya menghindari peningkatan beban pajak dengan melakukan penghindaran pajak. Maka berdasarkan rerangka pemikiran teoritis dan hasil riset empiris yang telah dipaparkan di atas maka dapat dirumuskan hipotesis penelitian sebagai berikut.

$\mathrm{H}_{3}$ : Profitabilitas berpengaruh positif terhadap penghindaran pajak.

Adanya perhatian dari pemerintah terhadap perusahaan besar dan pengawasan optimal dari investor institusional dapat mengontrol perilaku manajer.Penelitian Siegfried (1972) menyatakan bahwa ukuran perusahaan berpengaruh negatif terhadap tax avoidance. Hasil penelitian tersebut didukung oleh Dewi \& Noviari (2017) Serta serta Praditasari \& Setiawan (2017) yang juga menyatakan bahwa ukuran perusahaan berpengaruh negatif terhadap penghindaran pajak. Maka berdasarkan rerangka pemikiran teoritis dan hasil riset empiris yang telah dipaparkan di atas maka dapat dirumuskan hipotesis penelitian sebagai berikut.

$\mathrm{H}_{4}$ : Ukuran perusahaan memperkuat hubungan kepemilikan institusional dengan penghindaran pajak.

Komisaris independen bertanggung jawab mendorong diterapkannya good governance dalam perusahaan. Fungsi pengawasan yang dilakukan komisaris independen dinilai mampu meminimalisir perilaku menyimpang manajemen seperti penghindaran pajak.Penelitian oleh Praditasari \& Setiawan (2017) menyatakan bahwa ukuran perusahaan berpengaruh negatif terhadap tax avoidance. Hasil penelitian tersebut didukung oleh Dewi \& Noviari (2017) serta Kurniasih \& Sari (2013). Maka berdasarkan rerangka pemikiran teoritis dan hasil riset empiris yang telah dipaparkan di atas maka dapat dirumuskan hipotesis penelitian sebagai berikut.

$\mathrm{H}_{5}$ : Ukuran perusahaan memperkuat hubungan komisaris independen dengan penghindaran pajak.

Profitabilitas suatu perusahaan dapat diukur dengan menghubungkan antara keuntungan atau laba yang diperoleh dari kegiatan pokok perusahaan dengan kekayaan atau asset yang dimiliki untuk menghasilkan keuntungan perusahaan (operating asset) (Ratnasari \& Budiyanto, 2016). Hasil penelitian Asri \& Suardana (2016) menyatakanbahwa ukuran perusahaan berpengaruh pada penghindaran pajak.

$\mathrm{H}_{6}$ : Ukuran perusahaan memperlemah hubungan profitabilitas dengan penghindaran pajak. 


\section{METODE PENELITIAN}

Lokasi penelitian dalam penelitian ini adalah perusahaan manufaktur sub sektor makanan dan minuman yang terdaftar di Bursa Efek Indonesia (BEI) pada periode 2013-2017 dengan mengakses situs www.idx.co.id dan www.sahamok.com serta website perusahaan untuk mendapatkan data yang diperlukan.Pemilihan sub sektor makanan dan minuman yang terdaftar di BEI didasari atas kontribusi yang diberikan oleh sektor industri makanan dan minumanterhadap Produk Domestik Bruto (PDB) di Indonesia yang berperan sangat baik dibandingkan dengan cabang industri lain. Selain itu, adanya fenomena penghindaran pajak oleh PT Coca-Cola Indonesia yang menimbulkan kekurangan pembayaran pajak senilai Rp49,24 Miliar juga mendasari alasan pemilihan sub sektor makanan dan minuman.

Objek penelitian dalam penelitian ini adalah penghindaran pajak tahun 2013-2017 yang diuji dengan variabel kepemilikan institusional, komisaris independen, profitabilitas, serta ukuran perusahaan sebagai variabel pemoderasi pada perusahaan manufaktur sub sektor makanan dan minuman.

Variabel bebas (independen) dalam penelitian iniadalah kepemilikan institusional $\left(X_{1}\right)$, komisaris independen $\left(X_{2}\right)$, dan profitabilitas $\left(X_{3}\right)$.Variabel pemoderasi dalam penelitian iniadalah ukuran perusahaan $\left(\mathrm{X}_{4}\right)$.Variabel terikat (Y) dalam penelitian ini adalah penghindaran pajak.

Variabel kepemilikan institusional menurut Khurana \& Mose (2009) dapat diukur dengan rumus berikut:

Kepemilikan Institusional $=\frac{\text { proporsi saham dimiliki institusi }}{\text { jumlah saham diterbitkan }} \times 100 \%$

Pengukuran pada komisaris independen dilakukan dengan rumus berikut.

Komisaris Independen $=\frac{\text { jumlah dewan komisaris independen }}{\text { jumlah seluruh dewan komisaris }} \times 100 \%$.

ROA dipilih sebagai prroksi untuk mengukur profitabilitas

$\mathrm{ROA}=\frac{\text { earning after tax }(E A T)}{\text { total assets }}$

Ukuran perusahaan merupakan variabel moderasi dalam penelitian ini. Ukuran perusahaan merupakan suatu skala yang dapat diklasifikasikan besar kecilnya perusahaan menurut berbagai cara, antara lain: jumlah nilai aset, jumlah penjualan, jumlah tenaga kerja.Ukuran perusahaan diukur melalui logaritma natural (Ln) total aset (Jogiyanto, 2007). Menurut Richardson \& Lanis, (2012) Lanis \& Richardson (2011) rumus logaritma natural total aset adalah sebagai berikut.

Ukuran perusahaan $=$ Ln Total Aktiva

Penghindaran pajak merupakan variabel terikat dalam penelitian ini. Penghindaran pajak dalam penelitian ini diukur dengan pendekatan Cash Effective Tax Rate (CETR).

$$
\text { CETR }=\frac{\text { Pembayaran Pajak }}{\text { Laba sebelum pajak }}
$$

Populasi adalah wilayah generalisasi yang terdiri atas obyek/subyek yang mempunyai kualitas dan karakteristik tertentu yang ditetapkan oleh peneliti 
untuk dipelajari dan kemudian ditarik kesimpulannya (Sugiyono, 2017). Populasi dalam penelitian ini adalah perusahaan manufaktur sub sektor makanan dan minuman yang terdaftar di Bursa Efek Indonesia (BEI) pada periode 2013-2017 yang diakses melalui www.idx.co.id dan www.sahamok.com.

Pemilihan sampel dalam penelitian ini dilakukan dengan teknik purposive sampling. Kriteria pemilihan sampel dalam penelitian ini adalah sebagai berikut. Perusahaan merupakan perusahaan sub sektor makanan dan minuman yang terdaftar di Bursa Efek Indonesia periode 2013-2017.Perusahaan yang mempublikasikan laporan tahunan (annual report) dan laporan keuangan tahunan pada tahun 2013-2017 secara lengkap.Perusahaan menerbitkan laporan keuangan dengan mata uang rupiah. Perusahaan memiliki pre-tax income yang positif selama periode 2013-2017. Perusahaan tidak mengalami kerugian selama periode penelitian 2013-2017.

Adapun pada penelitian ini dilakukan pengamatan pada data laporan keuangan perusahaan dan laporan tahunan perusahaan manufaktur sub sektor makanan dan minuman yang terdaftar di Bursa Efek Indonesia (BEI) periode 2013-2017yang bersumber dari www.idx.co.id, www.sahamok.com,website masing-masing perusahaan, serta buku-buku dan jurnal yang terkait untuk dijadikan referensi penelitian.

Data sekunder dalam penelitian ini adalah laporan keuangan perusahaan manufaktur sub sektor makanan dan minuman di BEI tahun 2013-2017. Data laporan keuangan perusahaan dan laporan tahunan perusahaan manufaktur sub sektor makanan dan minuman yang terdaftar di Bursa Efek Indonesia (BEI) periode 2013-2017 diperoleh dari www.idx.co.id, www.sahamok.com, sertasitus resmi masing-masing perusahaan.

\section{HASIL DAN PEMBAHASAN}

Perusahaan food and beverage yang terdapat di Bursa Efek Indonesia berjumlah 18 perusahaan. Metode pengambilan sampel yang digunakan dalam penelitian ini adalah metode non probability dengan teknik purposive sampling, yaitu teknik penentuan sampel yang dipilih dari populasi yang tersedia dengan menggunakan kriteria yang telah ditentukan sebelumnya.

\section{Tabel 5. Proses Seleksi Sampel Penelitian}

\begin{tabular}{|c|c|c|}
\hline No & Kriteria & $\begin{array}{l}\text { Jumlah } \\
\text { Amatan }\end{array}$ \\
\hline 1. & Perusahaan food and beverageyang terdaftar di BEI tahun 2013-2017 & 18 \\
\hline 2. & $\begin{array}{l}\text { Perusahaan food and beverageyang tidak mempublikasikan laporan } \\
\text { keuangan secara lengkap pada tahun 2013-2017. }\end{array}$ & (5) \\
\hline \multirow[t]{4}{*}{3.} & $\begin{array}{l}\text { Perusahaan food and beverage yang mengalami kerugian pada tahun } \\
\text { 2013-2017. }\end{array}$ & (2) \\
\hline & Jumlah sampel akhir & 11 \\
\hline & Tahun pengamatan & 5 \\
\hline & Jumlah pengamatan & 55 \\
\hline
\end{tabular}

Sumber: Data Penelitian, 2019

Statistik deskriptif disajikan untuk memberikan informasi umum mengenai karakteristik variabel-variabel penelitian, mencakup nilai minimum, maksimum, mean, dan standar deviasi dari masing-masing variabel. Tabel 6 
menunjukkan statistik deskriptif dari variabel-variabel yang digunakan dalam penelitian ini.

Tabel 6. Statistik Deskriptif Variabel Penelitian

\begin{tabular}{llllll}
\hline Variabel & N & Min. & Max. & Mean & $\begin{array}{l}\text { Std. } \\
\text { Deviation }\end{array}$ \\
\hline Kepemilikan Institusional $\left(X_{1}\right)$ & 55 & 33,07 & 96,09 & 70,2689 & 18,57184 \\
Komisaris Independen $\left(X_{2}\right)$ & 55 & 33,00 & 57,00 & 36,7273 & 5,84191 \\
Profitabilitas $\left(X_{3}\right)$ & 55 & 0,01 & 0,67 & 0,1318 & 0,12984 \\
Ukuran Perusahaan $\left(X_{4}\right)$ & 55 & 20,58 & 32,15 & 28,1647 & 2,79790 \\
Penghindaran Pajak $(Y)$ & 55 & 0,03 & 0,98 & 0,4873 & 0,22025 \\
\hline
\end{tabular}

Sumber: Data Penelitian, 2019

Pada uji deskriptif yang telah dilakukan dijabarkan hasil mengenai nilai minimum dan maksimun untuk masing-masing variabel yang digunakan dimana terdapat empat variabel bebas dan satu variabel terikat. Selain nilai minimum dan maksimum, dijabarkan juga nilai mean dan std deviation dari masing-masing variabel.

Tabel 7. Hasil Uji Normalitas

\begin{tabular}{ll}
\hline & Unstandardized Residual \\
\hline $\mathrm{N}$ & 55 \\
Kolmogorov-Smirnov & 0,627 \\
Asymp. Sig. (2-tailed) & 0,103 \\
\hline
\end{tabular}

Sumber: Data Penelitian, 2019

Berdasarkan Tabel 7 dapat dilihat nilai Asymp. Sig. (2-tailed) sebesar 0,103 lebih besar dari 0,05 , sehingga data yang digunakan dinyatakan berdistribusi normal.

Tabel 8. Hasil Uji Autokorelasi

\begin{tabular}{lllllll}
\hline Model & $\mathrm{R}$ & $\mathrm{R}$ Square & $\begin{array}{l}\text { Adjusted } \\
\text { Square }\end{array}$ & $\begin{array}{l}\mathrm{R} \\
\text { Std. Error of the } \\
\text { Estimate }\end{array}$ & Durbin- Watson \\
\hline 1 & 0,951 & 0,905 & 0,890 & 0,03927 & 1,930 \\
\hline
\end{tabular}

Sumber: Data Penelitian, 2019

Tabel 8 menunjukkan bahwa nilai uji Durbin-Watson sebesar 1,930. Nilai dU untuk jumlah sampel 55dengan 3 variabel bebas $(\mathrm{k})$ serta level of significant 0,05 adalah 1,6815 dan nilai dL adalah 1,4523 . Nilai 4-dU adalah 2,3185, sehingga hasil uji autokorelasinya adalah $\mathrm{dU}<\mathrm{d}<(4-\mathrm{dU})$, yaitu 1,6815 $<1,930<$ 2,3185 maka dapat disimpulkan koefisien regresi bebas dari gangguan autokorelasi.

Tabel 9. Hasil Uji Heteroskedastisitas

\begin{tabular}{lll}
\hline Model & Sig. & Keterangan \\
\hline Kepemilikan Institusional $\left(\mathrm{X}_{1}\right)$ & 0,857 & Bebas Heteroskedastisitas \\
Komisaris Independen $\left(\mathrm{X}_{2}\right)$ & 0,081 & Bebas Heteroskedastisitas \\
Profitabilitas $\left(\mathrm{X}_{3}\right)$ & 0,143 & Bebas Heteroskedastisitas \\
Ukuran Perusahaan $\left(\mathrm{X}_{4}\right)$ & 0,194 & Bebas Heteroskedastisitas \\
Interaksi 1 $\left(\mathrm{X}_{1} \mathrm{X}_{4}\right)$ & 0,625 & Bebas Heteroskedastisitas \\
Interaksi 2 $\left(\mathrm{X}_{2} \mathrm{X}_{4}\right)$ & 0,130 & Bebas Heteroskedastisitas \\
Interaksi 3 $\left(\mathrm{X}_{3} \mathrm{X}_{4}\right)$ & 0,689 & Bebas Heteroskedastisitas \\
\hline
\end{tabular}

Sumber: Data Penelitian, 2019

Tabel 9 menunjukkan bahwa nilai signifikansi untuk variabel kepemilikan institusional $\left(X_{1}\right)$ sebesar 0,857 , variabel komisaris independen $\left(X_{2}\right)$ 
sebesar 0,081, variabel profitabilitas $\left(X_{3}\right)$ sebesar 0,143 , interaksi $1\left(X_{1} X_{4}\right)$ sebesar 0,625 , interaksi $2\left(X_{2} X_{4}\right)$ sebesar 0,130 , dan interaksi $3\left(X_{3} X_{4}\right)$ sebesar 0,689 . Hal ini menunjukkan bahwa nilai signifikansi masing-masing variabel serta interaksinya lebih besar dari 0,05 sehingga dapat disimpulkan bahwa model regresi bebas dari gejala heteroskedastisitas.

\section{Tabel 10. Hasil Uji Analisis Linier Berganda}

\begin{tabular}{|c|c|c|c|c|c|}
\hline \multirow[b]{2}{*}{ Model } & \multicolumn{2}{|c|}{$\begin{array}{l}\text { Unstandardized } \\
\text { Coefficients }\end{array}$} & $\begin{array}{l}\text { Standardized } \\
\text { Coefficients }\end{array}$ & \multirow[b]{2}{*}{$\mathrm{T}$} & \multirow[b]{2}{*}{ Sig. } \\
\hline & B & $\begin{array}{l}\text { Std. } \\
\text { Error }\end{array}$ & Beta & & \\
\hline (Constant) & 2,814 & 0,462 & & 6,098 & 0,000 \\
\hline $\begin{array}{l}\text { Kepemilikan Institusional } \\
\left(X_{1}\right)\end{array}$ & $-0,186$ & 0,040 & $-0,212$ & $-4,605$ & 0,000 \\
\hline Komisaris Independen $\left(X_{2}\right)$ & $-0,233$ & 0,110 & $-0,123$ & $-2,107$ & 0,040 \\
\hline Profitabilitas $\left(\mathrm{X}_{3}\right)$ & 0,333 & 0,019 & 0,997 & 17,131 & 0,000 \\
\hline
\end{tabular}

Sumber: Data Penelitian, 2019

Persamaan regresi yang dihasilkan melalui uji analisis linear berganda (Tabel 10) sebagai berikut.

$$
\mathrm{Y}=2,814+(-0,186) \mathrm{X}_{1}+(-0,233) \mathrm{X}_{2}+0,333 \mathrm{X}_{3}
$$

Nilai konstanta sebesar 2,814 menunjukkan bahwa jika variabel kepemilikan institusional $\left(X_{1}\right)$, komisaris independen $\left(X_{2}\right)$, dan profitabilitas $\left(X_{3}\right)$ sama dengan nol, maka variabel penghindaran pajak $(\mathrm{Y})$ tidak meningkat atau sama dengan 2,814 satuan.

Nilai $\beta_{1}=-0,186$ menunjukkan jika nilai kepemilikan institusional $\left(X_{1}\right)$ bertambah 1 satuan, maka nilai dari penghindaran pajak (Y) akan berkurang sebesar 0,186 satuan dengan asumsi variabel bebas lainnya dianggap konstan.

Nilai $\beta_{2}=-0,233$ menunjukkan jika nilai komisaris independen $\left(X_{2}\right)$ bertambah 1 satuan, maka nilai dari penghindaran pajak $(Y)$ akan berkurang sebesar 0,233 satuan dengan asumsi variabel bebas lainnya dianggap konstan.

Nilai $\beta_{3}=0,333$ menunjukkan jika nilai profitabilitas $\left(X_{3}\right)$ bertambah 1 satuan, maka nilai dari penghindaran pajak (Y) akan bertambah sebesar 0,333 satuan dengan asumsi variabel bebas lainnya dianggap konstan.

Tabel 11. Hasil Uji Analisis Regresi Moderasi

\begin{tabular}{|c|c|c|c|c|c|}
\hline \multirow[b]{2}{*}{ Model } & \multicolumn{2}{|c|}{$\begin{array}{l}\text { Unstandardized } \\
\text { Coefficients }\end{array}$} & $\begin{array}{l}\text { Standardized } \\
\text { Coefficients }\end{array}$ & \multirow[b]{2}{*}{$\mathrm{T}$} & \multirow[b]{2}{*}{ Sig. } \\
\hline & B & $\begin{array}{l}\text { Std. } \\
\text { Error }\end{array}$ & Beta & & \\
\hline (Constant) & $-10,659$ & 15,009 & & $-0,710$ & 0,481 \\
\hline $\begin{array}{l}\text { Kepemilikan } \\
\text { Institusional }\left(\mathrm{X}_{1}\right)\end{array}$ & 1,135 & 3,224 & 1,298 & 0,352 & 0,726 \\
\hline $\begin{array}{l}\text { Komisaris Independen } \\
\left(X_{2}\right)\end{array}$ & 2,529 & 4,221 & 1,332 & 0,599 & 0,552 \\
\hline Profitabilitas $\left(\mathrm{X}_{3}\right)$ & 1,385 & 0,738 & 4,151 & 1,882 & 0,066 \\
\hline $\begin{array}{l}\text { Ukuran Perusahaan } \\
\left(\mathrm{X}_{4}\right)\end{array}$ & 3,983 & 4,450 & 1,625 & 0,895 & 0,375 \\
\hline Interaksi $1\left(X_{1} X_{4}\right)$ & $-0,387$ & 0,125 & $-1,364$ & $-3,085$ & 0,011 \\
\hline Interaksi $2\left(X_{2} X_{4}\right)$ & $-0,826$ & 1,239 & $-1,868$ & $-0,667$ & 0,508 \\
\hline Interaksi $3\left(X_{3} X_{4}\right)$ & $-0,318$ & 0,122 & $-3,227$ & $-2,604$ & 0,020 \\
\hline
\end{tabular}

Sumber: Data Penelitian, 2019 
Persamaan regresi yang dihasilkan melalui uji analisis regresi moderasi (Tabel 11) adalah sebagai berikut.

$$
\begin{gathered}
Y=-10,659+1,135 X_{1}+2,529 X_{2}+1,385 X_{3}+3,983 X_{4}+(-0,387) X_{1} X_{4}+(- \\
0,826) X_{2} X_{4}+(-0,318) X_{3} X_{4}
\end{gathered}
$$

Nilai konstanta sebesar $-10,659$ menunjukkan bahwa jika variabel kepemilikan institusional $\left(X_{1}\right)$, komisaris independen $\left(X_{2}\right)$, profitabilitas $\left(X_{3}\right)$, ukuran perusahaan $\left(X_{4}\right)$, interaksi $1\left(X_{1} X_{4}\right)$, interaksi $2\left(X_{2} X_{4}\right)$, dan interaksi 3 $\left(\mathrm{X}_{3} \mathrm{X}_{4}\right)$ bernilai nol, maka variabel penghindaran pajak $(\mathrm{Y})$ yang diproksikan dengan CETR bernilai -10,659.

Nilai $\beta_{1}=1,135$ menunjukkan jika nilai kepemilikan institusional $\left(X_{1}\right)$ bertambah 1 satuan, maka nilai dari penghindaran pajak (Y) akan bertambah sebesar 1,135 satuan dengan asumsi variabel lainnya dianggap konstan.

Nilai $\beta_{2}=2,529$ menunjukkan jika nilai komisaris independen $\left(X_{2}\right)$ bertambah 1 satuan, maka nilai dari penghindaran pajak (Y) akan bertambah sebesar 2,529 satuan dengan asumsi variabel lainnya dianggap konstan.

Nilai $\beta_{3}=1,385$ menunjukkan jika nilai profitabilitas $\left(X_{3}\right)$ bertambah 1 satuan, maka nilai dari penghindaran pajak $(Y)$ akan bertambah sebesar 1,385 satuan dengan asumsi variabel lainnya dianggap konstan.

Nilai $\beta_{5}=-0,387$ menunjukkan jika nilai interaksi kepemilikan institusional dan ukuran perusahaan $\left(\mathrm{X}_{1} \mathrm{X}_{4}\right)$ meningkat sebesar 1 satuan, maka maka nilai dari penghindaran pajak (Y) akan berkurang -0,387 satuan dengan asumsi variabel lainnya dianggap konstan.

Nilai $\beta_{6}=-0,826$ menunjukkan jika nilai interaksi komisaris independen dan ukuran perusahaan $\left(X_{2} X_{4}\right)$ meningkat sebesar 1 satuan, maka maka nilai dari penghindaran pajak (Y) akan berkurang -0,826 satuan dengan asumsi variabel lainnya dianggap konstan.

Nilai $\beta_{7}=-0,318$ menunjukkan jika nilai interaksi profitabilitas dan ukuran perusahaan $\left(\mathrm{X}_{3} \mathrm{X}_{4}\right)$ meningkat sebesar 1 satuan, maka maka nilai dari penghindaran pajak (Y) akan berkurang -0,318 satuan dengan asumsi variabel lainnya dianggap konstan.

Tabel 12. Hasil Uji Koefisien Determinasi

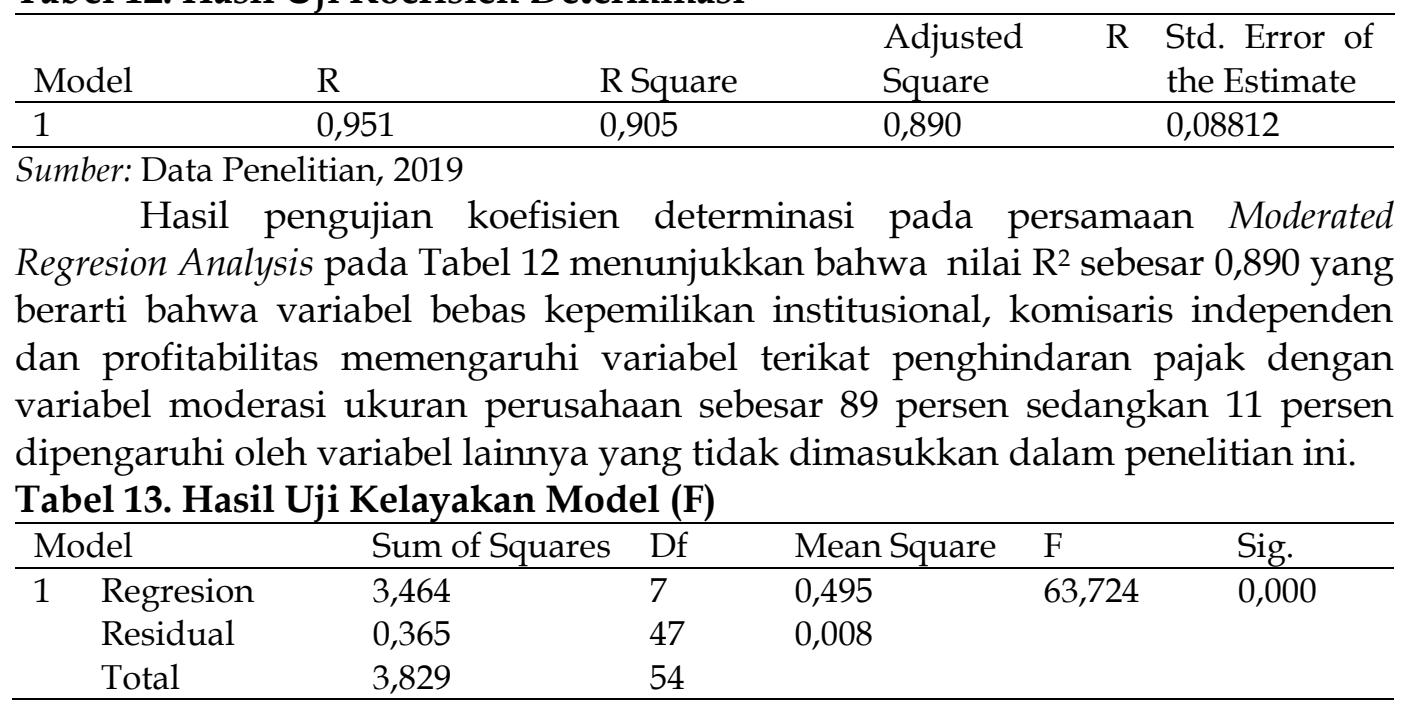

Sumber: Data Penelitian, 2019 
Berdasarkan hasil uji kesesuaian model tersebut dapat dilihat bahwa nilai dari uji F sebesar 63,724 dan nilai p-value (Sig. F) yakni 0,000 lebih kecil dari nilai $a=0,05$. Hal ini menunjukkan bahwa model persamaan dalam penelitian ini layak untuk digunakan.

Pengaruh kepemilikan institusional terhadap penghindaran pajak $\left(\mathrm{H}_{1}\right)$. Hasil yang didapatkan untuk pengujian hipotesis pertama adalah $\mathrm{H}_{1}$ diterima. Didapatkan koefisien regresi yaitu -0,186 serta didapatkan tingkat signifikansi 0,000. Nilai signifikansi yang didapatkan merupakan lebih kecil dari a yang telah ditentukan yaitu 0,05.Hasil tersebut menunjukkan semakin besar kepemilikan saham perusahaan oleh pihak institusi maka akan mengurangi peluang terjadinya penghindaran pajak.

Kondisi tersebut dapat terjadi karena kepemilikan institusional cenderung menghindari resiko deteksi atas kegiatan penghindaran pajak yangdapat merusak reputasi perusahaan, sehingga persentase kepemilikan saham oleh lembaga institusional yang tinggi akan meningkatkan kontrol terhadap manajemen untuk mematuhi peraturan perpajakan dan bertindak sesuai kepentingan perusahaan. Hasil penelitian ini mendukung teori keagenan yang menjelaskan kepemilikan institusional dapat mengatasi agency problem dalam perusahaan tersebut.

Penelitian sebelumnya Praditasari \& Setiawan (2017), Rosalia (2017), Merslythalia \& Lasmana (2016), serta Khurana \& Mose (2009) menemukan hasil yang sejalan dimana ditemukan pengaruh negatif dari kepemilikan institusional pada penghindaran pajak. Pengawasan yang tinggi oleh pihak institusi terhadap manajemen dapat mengurangi tindakan penghindaran pajak yang dilakukan manajemen.

Pengujian Hipotesis Kedua. Hasil yang didapatkan untuk pengujian hipotesis kedua adalah $\mathrm{H}_{2}$ diterima. Didapatkan koefisien regresiyaitu -0,233 serta didapatkan tingkat signifikansi 0,040. Nilai signifikansi yang didapatkan merupakan lebih kecil dari a yang telah ditentukan yaitu 0,05.Hasil tersebut berarti semakin besar jumlah anggota komisaris independen dalam perusahaan maka praktik penghindaran pajak dapat dikurangi.

Kondisi tersebut dapat terjadi karena komisaris independen bebas dari konflik kepentingan yang terjadi pada perusahaan danbertanggung jawab untuk mengawasi kinerja manajemen. Pengawasan yang dilakukan dapat mencegak tindakan menyimpang yang mungkin dilakukan oleh manajemen.Hasil penelitian ini mendukung teori keagenan yaitu perusahaan yang memiliki komisaris independen cenderung terhindar dari masalah keagenan (agency problem) dalam perusahaan tersebut.

Penelitian sebelumnya Wijayanti \& Merkusiwati (2017), Rosalia (2017), dan Diantari \& Ulupui (2016) menemukan hasil yang sejalan yaitu ditemukan pengaruh negatif darikomisaris independen terhadap penghindaran pajak.Komisaris independen melakukan pengawasan terhadap kinerja manajemen perusahaan sehingga dapat masalah keagenan terkait penghindaran pajak dapat diminimalisir.

Pengujian Hipotesis Ketiga. Hasil yang didapatkan untuk pengujian hipotesis ketiga adalah $\mathrm{H}_{3}$ diterima. Didapatkan koefisien regresi 0,333 serta didapatkan tingkat signifikansi 0,000. Nilai signifikansi yang didapatkan 
merupakan lebih kecil dari a yang telah ditentukan yaitu 0,05.Hasil ini memiliki arti dengan tingginya profitabilitas maka akan berdampak pada meningkatnya kemungkinan manajemen dalam melakukan penghindaran pajak.

Kondisi tersebut terjadi akibat adanya upaya penghindaran pajak oleh manajer untuk menghemat beban pajak perusahaan yang ikut meningkat seiring meningkatnya laba perusahaan. Hasil penelitian ini mendukung teori keagenan. Manajemen (agent) terpacu untuk meningkatkan laba perusahaan, namun menghindari peningkatan beban pajak sehingga manajemen terdorong untuk melakukan praktik penghindaran pajak.

Penelitian sebelumnya Putra \& Jati (2017), Praditasari \& Setiawan (2017), serta Dewi \& Noviari (2017) menemukan hasil yang sejalan dengan hasil dari penelitian ini yaitu ditemukannya pengaruh positif dari profitabilitas pada penghindaran pajak. Beban pajak yang meningkat seiring peningkatan laba mendorong perusahaan untuk menekan beban pajak.

Pengujian Hipotesis Keempat. Hasil yang didapatkan untuk pengujian hipotesis keempat adalah $\mathrm{H}_{4}$ diterima. Didapatkan koefisien regresiyaitu -3,085 serta didapatkan niai signifikansi yaitu 0,011. Nilai signifikansi dari hasil uji merupakan lebih rendah dari a yang telah ditentukan yaitu 0,05. Hasil tersebut menunjukkan semakin besar ukuran perusahaan maka pengaruh komisaris independen terhadap praktik penghindaran pajak akan semakin rendah.

Kondisi tersebut dapat terjadi karena ukuran perusahaan yang semakin besar akan menarik perhatian pemerintah dan fiskus terkait kepatuhan dalam membayar pajak. Perhatian pemerintah dan fiskus yang besar akan semakin mendorong investor institusional untuk meningkatkan kontrol terhadap manajemen untuk mematuhi peraturan perpajakan untuk menghindari risiko yangdapat merusak reputasi perusahaan.

Hasil penelitian ini mendukung teori biaya politik dimana teori tersebut menjelaskan bahwa perusahaan besar cenderung untuk tidak melakukan penghindaran pajak karena perusahaan besar akan menjadi sorotan pemerintah. Perusahaan besar dengan aset yang besar akan lebih mudah menarik perhatian fiskus terkait kepatuhan pembayaran pajak.

Pengujian Hipotesis Kelima. Hasil yang didapatkan untuk pengujian hipotesis kelima adalah $\mathrm{H}_{5}$ ditolak. Didapatkan koefisien regresiyaitu -0,667 serta didapatkan tingkat signifikansi 0,508. Nilai signifikansi yang didapatkan merupakan lebih besar dari a yang telah ditentukan yaitu 0,05.Hasil ini memiliki arti besar kecilnya ukuran perusahaan tidak ada dampaknya pada pengaruh komisaris independenpada praktik penghindaran pajak.

Kondisi tersebut dapat diakibatkan karena ukuran perusahaan tidak mampu memengaruhi fungsi pengawasan yang dilakukan komisaris independen. Komisaris independen tetap bertanggungjawab untuk melakukan pengawasan terhadap manajemen serta mencegah terjadinya praktik penghindaran pajak oleh manajemen, terlepas dari besar kecilnya ukuran perusahaan tersebut.

Hasil penelitian ini tidak dapat mendukung teori biaya politik dimana pada teori tersebut dijelaskan bahwa dengan adanya perhatian pemerintah pada perusahaan besar maka tindakan penghindaran pajak akan terminimalisir.Berdasarkan sampel yang diambil dalam penelitian ini tidak 
ditemukan perbedaan signifikan pada jumlah anggota komisaris independen antar perusahaan meskipun hasil pengukuran variabel ukuran perusahaan melalui logaritma natural total aset menunjukkan perbedaan ukuran perusahaan yang cukup beragam.

Pengujian Hipotesis Keenam. Hasil yang didapatkan untuk pengujian hipotesis keenam adalah $\mathrm{H}_{6}$ diterima. Didapatkan koefisien regresiyaitu -2,604 serta didapatkan tingkat signifikansi 0,020. Nilai signifikansi yang didapatkan merupakan lebih kecil dari a yang telah ditentukan yaitu 0,05. Hasil uji $t$ menunjukkan bahwa ukuran perusahaan secara statistik mampu memperlemah pengaruh profitabilitas terhadap penghindaran pajak $\left(\mathrm{H}_{5}\right.$ diterima). Artinya, semakin besar ukuran perusahaan maka pengaruh profitabilitas terhadap praktik penghindaran pajak akan semakin rendah.

Kondisi tersebut dapat terjadi karena semakin besar ukuran perusahaan akan meningkatkan pengawasan pemerintah, sehingga manajemen perusahaan menghindari praktik penghindaran pajak. Deteksi kegiatan penghindaran pajak dapat merusak reputasi perusahaan.Hasil penelitian ini mendukung teori biaya politik dimana teori tersebut menjelaskan bahwa perusahaan besar cenderung untuk tidak melakukan penghindaran pajak karena perusahaan besar akan menjadi sorotan pemerintah.

\section{SIMPULAN}

Berdasarkan hasil pembahasan hasil yang telah diuraikan pada bab sebelumnya, maka dapat diambil simpulan berikut.

Corporate governance yang diproksikan oleh kepemilikan institusionalberpengaruh negatif terhadap penghindaran pajak. Semakin besar proporsi kepemilikan saham oleh lembaga institusional, maka tindakan penghindaran pajak akan semakin rendah. Corporate governance yang diproksikan oleh komisaris independen berpengaruh negatif terhadap penghindaran pajak. Semakin besar proporsi komisaris independen dalam perusahaan, maka tindakan penghindaran pajak akan semakin rendah.

Profitabilitas berpengaruh positif terhadap penghindaran pajak. Semakin tinggi profitabilitas perusahaan maka kecendrungan manajemen untuk melakukan penghindaran pajak akan semakin tinggi. Ukuran perusahaan mampu memperkuat pengaruh negatif dari kepemilikan institusional terhadap penghindaran pajak. Semakin besar perusahaan maka akan memperkuat pengaruh komisaris independen terhadap penghindaran pajak sehingga penghindaran pajak akan semakin rendah.

Ukuran perusahaan tidak mampu memoderasi pengaruh komisaris independen terhadap penghindaran pajak. Semakin besar maupun kecil ukuran perusahaan tidak akan memengaruhi hubungan komisaris independen terhadap penghindaran pajak.Ukuran perusahaan memperlemah pengaruh positif dari profitabilitas terhadap penghindaran pajak. Semakin besar perusahaan maka akan memperlemah pengaruh profitabilitas terhadap penghindaran pajak sehingga penghindaran pajak akan semakin rendah. 


\section{REFERENSI}

Anderson, R. C., \& Reeb., D. M. (2003). Founding-Family Ownership and Firm Performance: Evidence from the S\&P 500. The. Journal of Finance., 53(3).

Arianandini, P. W., \& Ramantha, I. W. (2018). Pengaruh Profitabilitas, Leverage, dan Kepemilikan Institusional pada Tax Avoidance. E-Jurnal Akuntansi Universitas Udayana, 22(3).

Asri, I. A. T. Y., \& Suardana, K. A. (2016). Pengaruh Proporsi Komisaris Independen, Komite Audit, Preferensi Risiko Eksekutif dan Ukuran Perusahaan pada Penghindaran Pajak. E-Jurnal Akuntansi Universitas Udayana., 16(1).

Chen, S., Chen, X., Cheng, Q., \& Shevlin, T. (2010). Are Family Firms More Tax Aggressive Than Non-Family Firms? Journal of Financial Economics, 95, 4161.

Damayanti, F., \& Susanto, T. (2015). Pengaruh Komite Audit, Kualitas Audit, Kepemilikan Institusional, Risiko Perusahaan dan Return On Assets terhadap Tax Avoidance. Jurnal Bisnis Dan Manajemen, 5(2).

Dewi, N. L. P. P., \& Noviari, N. (2017). Pengaruh Ukuran Perusahaan, Leverage, Profitabilitas dan Corporate Social Responsibility Terhadap Penghindaran Pajak (Tax Avoidance). E-Jurnal Akuntansi Universitas Udayana, 21(1).

Diantari, P. R., \& Ulupui, I. G. K. A. (2016). Pengaruh Komite Audit, Proporsi Komisaris Independen, dan Proporsi Kepemilikan Institusional Terhadap Tax Avoidance. E-Jurnal Akuntansi Udayana., 16(1).

Ginting, S. (2016). Pengaruh Corporate Governance dan Kompensasi Rugi Fiskal Terhadap Penghindaran Pajak dengan Ukuran Perusahaan sebagai Variabel Moderating. Jurnal Wira Ekonomi Mikroskil, 2(6).

Jogiyanto, H. (2007). Sistem Informasi Keprilakuan. Yogyakarta: Andi.

Khurana, I. K., \& Moser, W. J. (2009). Institutional Ownership and Tax Aggressiveness.

Kotler, A. (2012). Prinsip-Prinsip Pemaasaaran.

Kurniasih, T., \& Sari, R. M. M. (2013). Pengaruh Return on Aset, Leverage, Corporate Governance, Ukuran Perusahaan dan Kompensasi Rugi Fiskal pada Tax Avoidance. Buletin Studi Ekonomi. Tema, 18(1).

Lin, C., Wu, Y. S., \& Chen, J. C. V. (2013). Electronic word-of-mouth: The moderating roles of product involvement and brand image. Proceedings of 2013 International Conference on Technology Innovation and Industrial Management, 39-47.

Merslythalia, R., \& Lasmana, M. S. (2016). Pengaruh Kompetensi Eksekutif, Ukuran Perusahaan, Komisaris Independen, dan Kepemilikan Institusional terhadap Tax Avoidance. Jurnal Ilmiah Akuntansi Dan Bisnis., 11.

Ngadiman, \& Puspitasari, C. (2014). Pengaruh Leverage, Kepemilikan Institusional, dan Ukuran Perusahaan terhadap Penghindaran Pajak. Jurnal Akuntansi Untar.

Praditasari, N. K. A., \& Setiawan, P. E. (2017). Pengaruh Good Corporate Governance, Ukuran Perusahaan, Leverage Dan Profitabilitas Pada Tax Avoidance. E-Jurnal Akuntansi Universitas Udayana., 19(2).

Putra, I. G. L. N. D. C., \& Merkusiwati, N. K. L. A. (2016). Pengaruh Komisaris Independen, Leverage, Size dan Capital Intensity Ratio pada Tax Avoidance. E-Jurnal Akuntansi Universitas Udayana., 17(1). 
Putra, I. M. A. D., \& Jati, I. K. (2017). Analisis Faktor-Faktor yang Mempengaruhi Kepatuhan Wajib Pajak Kendaraan Bermotor Di Kantor Bersama Samsat Tabanan. E-Journal Akuntansi Universitas Udayana, Vol.18(No. 1), 557-586.

Ratnasari, L., \& Budiyanto. (2016). Pengaruh Leverage, Likuiditas, Ukuran Perusahaan terhadap Profitabilitas pada Perusahaan Otomotif di BEI. Jurnal Ilmu Dan Riset Manajemen, 5(6).

Richardson, G., \& Lanis, R. (2012). Corporate Social Responsibility and Tax Aggressiveness, 1-49. https:// doi.org/10.3386/w19846

Rinaldi, \& Cheisviyanny, C. (2015). Pengaruh Profitabilitas, Ukuran Perusahaan dan Kompensasi Rugi Fiskal terhadap Tax Avoidance. Jurnal Fakultas Ekonomi Universitas Padang.

Rosalia, Y. (2017). Pengaruh Profitabilitas, Likuiditas dan Corporate Governance terhadap Penghindaran Pajak. Jurnal Ilmu Dan Riset Akuntansi, 6(3).

Saputra, M. D. R., \& Asyik, N. F. (2017). Pengaruh Profitabilitas, Leverage dan Corporate Governance terhadap Tax Avoidance. Jurnal Ilmu Dan Riset Akuntansi, 6(8).

Siegfried, J. J. (1972). The Relationship between Economic Structure and the Effect of Political Influence: Empirical Evidence from the Corporation Income Tax Program. Thesis. University of Wisconsin-Madison.

Sindonews.com. (2016). Kesadaran Rendah Bayar Pajak RI jadi Sorotan. Retrieved from ekbis.sindonews.com/newsread/1157117/33/kesadaranrendah-bayar-pajak-ri-jadi-sorotan-1479730505?espv=1

Sugiyono. (2017). Metodologi Penelitian Kuantitatif, Kualitatif, dan RED. Bandung: CV Alfabeta.

Utari, N. K. Y., \& Supadmi, N. L. (2017). Pengaruh Corporate Governance, Profitabilitas Dan Koneksi Politik Pada Tax Avoidance. E-Jurnal Akuntansi Universitas Udayana, 18(3).

Wijayanti, Y. C., \& Merkusiwati, N. K. L. A. (2017). Pengaruh Proporsi Komisaris Independen, Kepemilikan Institusional, Leverage, dan Ukuran Perusahaan pada Penghindaran Pajak. E-Jurnal Akuntansi Universitas Udayana, 20(1).

Wirawan, I. G. H. K., \& Sukartha, I. M. (2018). Pengaruh Kepemilikan Keluarga dan Ukuran Perusahaan Pada Agresivitas Pajak dengan Corporate Governance Sebagai Variabel Pemoderasi. E-Jurnal Akuntansi Universitas Udayana, 23(1). 